\title{
EVALUATION OF CHEMICAL AND BIOLOGICAL TREATMENTS TO DEGRADE OIL PALM EMPTY FRUIT BUNCHES (Elaeis guineensis Jacq.) AND THEIR POTENTIAL USE
}

\section{JESUS DAVID CASTAÑO*; CRISTHIAN CAMILO CRESPO* and ESPERANZA TORRES*}

\begin{abstract}
The exploitation of oil palm generates lignocellulosic wastes, also known as oil palm empty fruit bunches $(E F B)$, which are difficult to biodegrade and are mainly composed of cellulose, hemicellulose and lignin. The presence of lignin impedes the use of the cellulose from this biomass in industrial processes. This study evaluated the effect of different chemical and biological treatments to remove the lignin present in the EFB from oil palm. The conventional kraft method, the soda-anthraquinone pulping process, microwaveassisted hydrogen peroxide degradation and the peroxy-monophosphoric acid method were the chemical treatments evaluated. Meanwhile, the four biological treatments were tested using different lignocellulolytic native fungi from the genera Xylaria, Psilocybe and Agrocybe. The results showed a greater reduction of the lignin content with an enrichment of cellulose using the kraft method and the soda-anthraquinone pulping process. For the biological treatments, the fungus Agrocybe sp. showed a selective delignification, exhibiting a remarkable potential for the utilisation of cellulose present in this type of waste. In contrast, the fungus Psilocybe sp. showed high non-selective fibre degradation, which could be used for bioremediation and composting systems.
\end{abstract}

Keywords: lignin removal, empty fruit bunch, cellulose, chemical treatment, macrofungi.

Date received: 28 August 2016; Sent for revision: 16 March 2017; Received in final form: 15 Jan 2019; Accepted: 15 April 2019.

\section{INTRODUCTION}

Colombia is the fourth largest producer of palm oil after Indonesia, Malaysia and Thailand and is the primary producer in the Americas. The exploitation of oil palm supplies the raw material for oil, edible fats and soaps, among other industries (Shuit et al., 2009). However, during industrial transformation, when fruit removal and oil extraction are performed, a large amount of lignocellulosic wastes that undergo slow degradation is produced. Average

Agronomy Department, National University of Colombia,
Cra 45, Bogotá, Colombia.

E-mail: etorresr@unal.edu.co oil palm mills are estimated to have the capacity to process $100000 \mathrm{t} \mathrm{yr}^{-1}$ of fruit bunches, producing between 20000 and $25000 \mathrm{t}$ of empty fruit bunches (EFB) $(20 \%-25 \%$ of the total biomass processed) (Manjarrés et al., 2011; Castañeda and Romero, 2012). The planting area reported for Colombia in 2014 was 450000 ha, resulting in the production of approximately one million tonnes of lignocellulosic wastes (Fedepalma, 2015). At the global level, the production of palm wastes is estimated to be over 190 million tonnes (Awalludin et al., 2015).

The vast quantity of EFB generated by year and increased degradation time in the field cause subsequent environmental problems. The slow degradation of these EFB is increased not only for 
its lignocellulosic components but also by the bunches sterilised during the crude oil extraction, which causes the microorganisms and enzymes capable of degrading this biomass to be removed (Prasertsan and Prasertsan, 1996). Nevertheless, this EFB is a potential biomass to produce biofuels and other chemical compounds that might be useful in the fields of energy, industry and agriculture. Therefore, methodologies to accelerate the degradation process, either by selective or general lignin removal of the cell wall components are relevant. For instance, the selective removal of lignin would increase the yield of cellulose, which can be harnessed in areas such as the paper industry, bioethanol production (Shuit et al., 2009), and biohydrogen production (Kothari et al., 2010). Also, the reduced lignin content of treated EFB can increase its animal digestibility, which in turn favours its potential use as forage in animal feed (Jung et al., 2012). Meanwhile, with the general removal and recycling of the cell wall components, the wastes could be promoted as soil fertilisers (Kayikcioglu, 2013; Gandahi and Hanafi, 2014).

Among the chemical delignification treatments, the kraft method and the soda-anthraquinone pulping process are widely used in the industrial pulping processes of wood (De Almeida and Gomide, 2013; Pinto et al., 2015). These treatments are characterised by the use of high temperatures and the production of pollutants. For this reason, several alternatives for chemical treatments that do not require the use of high temperature have been developed to reduce the pollution rates, for example, the alkaline hydrogen peroxide treatment (Zhao et al., 2009; Sun et al., 2000) and the use of peroxy acids (Springer, 1994; 1997).

Another alternative for lignin degradation with an environmental-friendly approach includes biological treatments that use organisms or enzymes. Fungi are essential for this type of process because they modify lignin using ligninolytic enzymes such as laccases and peroxidases; brown rot fungi are also essential in some non-enzymatic systems, such as the Fenton method (Cullen and Kersten, 2004; Martínez et al., 2005; Arantes et al., 2012). Whereas white rot basidiomycetes are recognised as having the best characteristics to degrade plant material - completely altering the lignocellulosic structure - some of the ascomycetes, known as soft rot fungi, are capable of modifying the lignin without dramatically altering the structure. This enables the subsequent use of the cellulose and other fibres (Kuhad et al., 1997; Hatakka and Hammel, 2010; Liers et al., 2011). Notably, this activity could be selective or non-selective, that is, it could induce the exclusive degradation of lignin or the simultaneous degradation of all components of the plant cell wall, including cellulose, hemicellulose and lignin (Arantes et al., 2012).
This study evaluates and compares the effect of four chemical and biological treatments on the oil palm EFB to determine the effectiveness and selectivity of each in the degradation of these agroindustrial wastes.

\section{MATERIALS AND METHODS}

\section{Plant Material}

EFB was obtained immediately after oil extraction from the oil palm extraction processing plant Unipalma S.A., which is located in Cumaral, Meta, Colombia ( $4^{\circ} 13^{\prime} 33^{\prime \prime}$ north latitude, $73^{\circ} 14^{\prime}$ $50^{\prime \prime}$ west longitude). The material was dried at $70^{\circ} \mathrm{C}$ for four days, milled and sifted with a $10 \mathrm{~mm}$ and 1 $\mathrm{mm}$ sieve, and sterilised at $121^{\circ} \mathrm{C}$ for $20 \mathrm{~min}$ before being used for the biological treatments. The $1 \mathrm{~mm}$ sieved samples were used for all cases except when the treatments involved the direct growth of fungi (solid-state fermentation). Each of these treatments was performed in triplicate, and the percent yield was determined by calculating the ratio between the mass recovered at the end of the treatment and the starting mass.

\section{Chemical Treatments}

Kraft pulping. The sample was subjected to kraft pulping according to Oudia et al. (2007). A total of $10 \mathrm{~g}$ of palm rachis $(1 \mathrm{~mm})$ was weighed and placed in a high-pressure reactor. Thereafter, $70 \mathrm{ml}$ (for a 7:1 proportion) of pulping liquor was added. The pulping liquor was an aqueous solution of $\mathrm{NaOH}$ $(0.70 \mathrm{M})$ and $\mathrm{Na}_{2} \mathrm{~S}(0.15 \mathrm{M})$. The mixture was heated at $160^{\circ} \mathrm{C}$ for $2 \mathrm{hr}$. The resulting solid was thoroughly filtered and washed with hot distilled water until a colourless supernatant was observed. The treated rachis was dried at $50^{\circ} \mathrm{C}$ for $24 \mathrm{hr}$.

Soda-anthraquinone pulping process. An adaptation of the treatment proposed by Nandkumar (2009) was performed. A total of $10 \mathrm{~g}$ of palm rachis $(1 \mathrm{~mm})$ was placed in a high-pressure reactor, and $50 \mathrm{ml}$ (for a 5:1 proportion) of the pulping liquor was added (4.20 $\mathrm{M} \mathrm{NaOH}, 0.1 \%$ anthraquinone). This mixture was subjected to $160^{\circ} \mathrm{C}$ for $2 \mathrm{hr}$. The resulting solid was thoroughly filtered and washed with hot distilled water until a colourless supernatant was observed. The treated rachis was dried at $50^{\circ} \mathrm{C}$ for $24 \mathrm{hr}$.

Microwave-assisted hydrogen peroxide treatment. An adaptation of the treatment proposed by Infante et al. (2007) was performed. A total of $10 \mathrm{~g}$ of palm rachis $(1 \mathrm{~mm})$ was weighed and placed in a 250 $\mathrm{ml}$ beaker with $100 \mathrm{ml}$ of $30 \%$ hydrogen peroxide $\left(\mathrm{H}_{2} \mathrm{O}_{2}\right)$. Once the sample was completely wetted, the partially covered beaker was placed inside a 
microwave (LG) with an output power of $900 \mathrm{~W}$ and a frequency of $2450 \mathrm{MHz}$. The sample was subjected to three irradiation cycles of $10 \mathrm{~s}$ with 30 s intervals between each cycle. Subsequently, 100 $\mathrm{ml}$ of $1 \% \mathrm{NaOH}$ was added, and the mixture was allowed to stand for $30 \mathrm{~min}$. Excessive foaming was avoided using a cold-water bath to cool the mixture. After $30 \mathrm{~min}, 250 \mathrm{ml}$ of distilled $\mathrm{H}_{2} \mathrm{O}$ was added. The resulting samples were thoroughly filtered and washed with hot distilled water until a colourless supernatant was observed. The treated rachis was dried at $50^{\circ} \mathrm{C}$ for $24 \mathrm{hr}$.

Peroxy-monophosphoric acid treatment. The treatment method proposed by Springer (1997) was followed. A total of $10 \mathrm{~g}$ of palm rachis $(1 \mathrm{~mm})$ was immersed in $0.1 \mathrm{M}$ sulphuric acid $\left(\mathrm{H}_{2} \mathrm{SO}_{4}\right)$ for 30 min and then thoroughly washed with hot distilled water. The sample was filtered and dried at $50^{\circ} \mathrm{C}$ for $24 \mathrm{hr}$. A solution of $3.8 \%$ peroxy-monophosphoric acid $\left(\mathrm{H}_{3} \mathrm{PO}_{5}\right)$ was prepared by hydrolysing 32.38 $\mathrm{g}$ of potassium peroxy-diphosphate $\left(\mathrm{K}_{4} \mathrm{P}_{2} \mathrm{O}_{8}\right)$ in $260 \mathrm{ml}$ of a $3.80 \mathrm{M}$ nitric acid $\left(\mathrm{HNO}_{3}\right)$ solution. The hydrolysis was performed at $50^{\circ} \mathrm{C}$ for 30 min. The residue obtained during the treatment with $\mathrm{H}_{2} \mathrm{SO}_{4}$ was placed in a beaker in which the peroxy-monophosphoric acid solution was added, maintaining a ratio of 25:1 with respect to the initial amount of rachis. The mixture was left standing at room temperature for $40 \mathrm{hr}$. Subsequently, washes with 10 volumes of $100 \mathrm{ml}$ of $1 \% \mathrm{NaOH}$ were performed at $60^{\circ} \mathrm{C}$, followed by hot water washes. The sample obtained was dried at $50^{\circ} \mathrm{C}$ for $24 \mathrm{hr}$.

\section{Biological Treatments}

Fungal strains. Two of the strains used were fungi from the genera Agrocybe and Psilocybe, which were isolated from Unipalma S.A. plantation ( $4^{\circ} 13^{\prime} 33^{\prime \prime}$ north latitude, $73^{\circ} 14^{\prime} 50^{\prime \prime}$ west longitude), and DNA was extracted for molecular identification using the internal transcribed spacer region (ITS) from rDNA (ITS1-5'-TCCGTAGGTGAACCTGCGG-3' and ITS45'-TCCTCCGCTTATTGATATGC-3') (Table 1). The other was a strain from the genus Xylaria isolated from a high Andean forest ecosystem in the region of San Antonio del Tequendama (Cundinamarca)

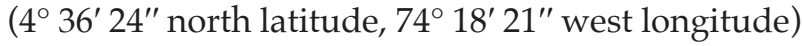
(Castaño et al., 2015). The strains were maintained at $4^{\circ} \mathrm{C}$ in wheat bran agar media [50 $\mathrm{g} \mathrm{litre}^{-1}$ wheat bran, $17 \mathrm{~g}$ litre ${ }^{-1}$ agar, $1.4 \mathrm{~g}$ litre ${ }^{-1}\left(\mathrm{NH}_{4}\right)_{2} \mathrm{SO}_{4^{\prime}} 2 \mathrm{~g}$ litre $^{-1} \mathrm{KH}_{2} \mathrm{PO}_{4} ; 0.4 \mathrm{~g}$ litre ${ }^{-1} \mathrm{CaCl}_{2} .2 \mathrm{H}_{2} \mathrm{O} ; 0.3 \mathrm{~g}$ litre $^{-1}$ $\mathrm{MgSO}_{4} .7 \mathrm{H}_{2} \mathrm{O} ; 5 \mathrm{mg}$ litre ${ }^{-1} \mathrm{FeSO}_{4} \cdot 7 \mathrm{H}_{2} \mathrm{O} ; 1.18 \mathrm{mg}$ litre $^{-1} \mathrm{MnSO}_{4} \cdot \mathrm{H}_{2} \mathrm{O} ; 1.4 \mathrm{mg}$ litre ${ }^{-1} \mathrm{ZnSO}_{4} \cdot 7 \mathrm{H}_{2} \mathrm{O}$, and $2.6 \mathrm{mg}$ litre $\left.^{-1} \mathrm{CoCl}_{2} .6 \mathrm{H}_{2} \mathrm{O}\right]$ and were preserved in slant tubes with a layer of mineral oil in the culture collection of the Agrobiotechnology Laboratory at the Universidad Nacional de Colombia. To obtain the fresh inocula needed for the testing treatments, fungi were inoculated in plates with the same media and incubated at $28^{\circ} \mathrm{C}$ for seven days.

Treatment with crude extract of the fungus Xylaria $s p$. A total of $10 \mathrm{~g}$ of rachis palm $(1 \mathrm{~mm})$ was weighed and placed in a $250 \mathrm{ml}$ Erlenmeyer flask, to which $100 \mathrm{ml}$ of crude extract of the fungus Xylaria sp. culture was added. The crude extract was obtained by culturing for six days under submerged fermentation, as described by Castaño et al. (2015). The initial $\mathrm{pH}$ of the crude extract was 5.0, and the laccase activity was 17416 U.litre $^{-1}$, determined as described by Castaño et al. (2015). The Erlenmeyer flask was incubated at $40^{\circ} \mathrm{C}$ for $48 \mathrm{hr}$ with orbital shaking at $150 \mathrm{rpm}$. This temperature was chosen considering the optimal temperature and thermal stability for this enzyme as discussed by Castaño et al. (2015). The $48 \mathrm{hr}$ of treatment was established analysing the enzyme stability at $40^{\circ} \mathrm{C}$ for different periods of time. After $48 \mathrm{hr}$ of incubation at $40^{\circ} \mathrm{C}$, the enzyme retained around $5 \%$ of its initial activity, which was deemed as an activity level low enough as to not extend the incubation any longer while still

TABLE 1. TAXONOMIC CHARACTERISATION OF ISOLATED STRAINS

\begin{tabular}{|c|c|c|c|c|c|c|}
\hline Strain & Genus & Closest relative sequence & $\%$ Coverage & $\%$ Similarity & Access number & E value \\
\hline UPB1 & Agrocybe sp. & $\begin{array}{l}\text { Agrocybe praecox isolate AFTOL-ID } \\
72818 \mathrm{~S} \text { ribosomal RNA gene, partial } \\
\text { sequence; internal transcribed spacer } 1 \text {, } \\
5.8 \mathrm{~S} \text { ribosomal RNA gene, and internal } \\
\text { transcribed spacer 2, complete sequence; } \\
\text { and } 25 \mathrm{~S} \text { ribosomal RNA gene, } \\
\text { partial sequence }\end{array}$ & 97 & 83 & AY818348.1 & $2,00 \mathrm{E}-172$ \\
\hline UPB6 & Psilocybe sp. & $\begin{array}{l}\text { Psilocybe coprophila strain CBS } 417.8218 \mathrm{~S} \\
\text { ribosomal RNA gene, partial sequence; } \\
\text { internal transcribed spacer 1, } 5.8 \mathrm{~S} \text { ribosomal } \\
\text { RNA gene, and internal transcribed spacer } 2 \text {, } \\
\text { complete sequence; and } 28 \mathrm{~S} \text { ribosomal } \\
\text { RNA gene, partial sequence }\end{array}$ & 100 & 98 & HM035073.1 & 0.0 \\
\hline
\end{tabular}


obtaining as much degradation as possible (data not shown). The samples obtained were thoroughly filtered and washed using distilled water until a colourless supernatant was observed. The treated rachis was dried at $50^{\circ} \mathrm{C}$ for $24 \mathrm{hr}$. A control incubating the rachis with uninoculated liquid medium was included.

Fungal growth on EFB. Solid-state fermentation (SSF) was performed with each of the three strains of fungi. A total of $12 \mathrm{~g}$ of palm rachis $(10 \mathrm{~mm})$ was weighed and placed in a $250 \mathrm{ml}$ glass flask with $30 \mathrm{~mL}$ of a salt solution composed of: $1.4 \mathrm{~g}^{\text {litre }}{ }^{-1}$ $\left(\mathrm{NH}_{4}\right)_{2} \mathrm{SO}_{4^{\prime}} 2 \mathrm{~g}$ litre ${ }^{-1} \mathrm{KH}_{2} \mathrm{PO}_{4^{\prime}} 0.4 \mathrm{~g}$ litre ${ }^{-1} \mathrm{CaCl}_{2} \cdot 2 \mathrm{H}_{2} \mathrm{O}$, $0.3 \mathrm{~g}$ litre ${ }^{-1} \mathrm{MgSO}_{4} \cdot 7 \mathrm{H}_{2} \mathrm{O}, 5 \mathrm{mg}$ litre ${ }^{-1} \mathrm{FeSO}_{4} \cdot 7 \mathrm{H}_{2} \mathrm{O}, 1.18$ $\mathrm{mg}$ litre $\mathrm{MnSO}_{4} \cdot \mathrm{H}_{2} \mathrm{O}, 1.4 \mathrm{mg}$ litre ${ }^{-1} \mathrm{ZnSO}_{4} \cdot 7 \mathrm{H}_{2} \mathrm{O}, 2.6$ $\mathrm{mg}$ litre ${ }^{-1} \mathrm{CoCl}_{2} \cdot 2 \mathrm{H}_{2} \mathrm{O}$ and $1.5 \mathrm{mg}$ litre ${ }^{-1} \mathrm{CuSO}_{4} \cdot 5 \mathrm{H}_{2} \mathrm{O}$. The material was sterilised at $121^{\circ} \mathrm{C}$ for $15 \mathrm{~min}$, and the substrate was inoculated using three mycelia disks of $5 \mathrm{~mm}$ diameter; the mycelia had been previously grown in wheat bran agar for one week. The experiment was carried out in a Sanyo MLR$351 \mathrm{H}$ phytotron, under dark conditions, at $28^{\circ} \mathrm{C}$ and at a relative humidity of $90 \%$ for three months to ensure the total fungal colonisation of the substrate and also because a significantly higher degradation of cellulose, hemicellulose and lignin was found in the substrate at the third month of incubation (data not shown), after which the material was dried at $50^{\circ} \mathrm{C}$ for $24 \mathrm{hr}$; the residual biomass of each treatment was then weighed. The fibres were washed with distilled water to remove parts of the mycelium. Finally, the treated rachis was dried at $50^{\circ} \mathrm{C}$ for $24 \mathrm{hr}$ before being milled and sifted with a $1 \mathrm{~mm}$ sieve for fibre analysis. A control consisting of incubating the rachis with an uninoculated salt solution was included.

\section{Electron Microscopy}

Variation in the structural stability of the palm fibres that had been subjected to biological treatments was determined by scanning electron microscopy (SEM), according to the methodology reported by Xian-Ling et al. (2012). The experiments were conducted at the Life Science Microscopy Facility (LFMF) at Purdue University, USA.

\section{Fibre Determination}

The determination of lignin, cellulose and hemicellulose content was performed using standard methods (Van Soest et al., 1991) implemented in the Laboratory of Ruminant Nutrition, Faculty of Veterinary Medicine, National University of Colombia, Bogotá.

\section{Statistical Analysis}

Statistical analysis was performed using the software SAS version 9.2; an analysis of variance (ANOVA) was performed, and a comparison of means was conducted using the Tukey test with an alpha value of 0.05 .

\section{RESULTS AND DISCUSSION}

\section{Efficiency of Chemical and Biological Treatments}

The effect of the chemical and biological treatments performed on the empty palm rachises was calculated based on the yield obtained after the treatment, where a percentage close to $100 \%$ implies a minimal loss of biomass. The results showed that in the case of the chemical treatments, the yield of the kraft pulping and the soda-anthraquinone pulping processes were less than $48 \%$ and $32 \%$, respectively, representing a high loss of the starting material during the processes (Table 2). These results agree with other studies using the same treatments for the delignification of other lignocellulosic substrates such as aspen, poplar, pine, and beech, wherein the pulp yield was around $50 \%$ or even lower (Buzala et al., 2017). Different researchers have shown that the content of alkali charge, temperature, and treatment time are negatively correlated with yield while positively correlated with delignification (Anupam et al., 2018; Leh et al., 2008; Oldroyd and Wadley, 1997). In addition, important interactions have been described between temperature and treatment time (Leh et al., 2008), as well as temperature and alkali charge (Oldroyd and Wadley, 1997) in the delignification process of different lignocellulosic substrates, including EFB. These interactions and

TABLE 2. PERCENTAGE OF YIELD FOR THE CHEMICAL AND BIOLOGICAL TREATMENTS TESTED

\begin{tabular}{lccc}
\hline Chemical treatments & \% Yield & Biological treatments & $\%$ Yield \\
\hline Kraft pulping & $46.8-48.0^{\mathrm{a}}$ & Crude extract Xylaria sp. & $95.8-97.0^{\mathrm{a}}$ \\
Soda-anthraquinone pulping & $30.6-32.0^{\mathrm{b}}$ & Xylaria sp. & $76.29-78.31^{\mathrm{b}}$ \\
Hydrogen peroxide & $74.1-75.9^{\mathrm{c}}$ & Agrocybe sp. & $66.39-72.19^{\mathrm{c}}$ \\
Peroxy-monophosphoric acid & $74.0-74.3^{\mathrm{c}}$ & Psilocybe sp. & $39.01-44.07^{\mathrm{d}}$ \\
\hline
\end{tabular}

Note: Percent yield is calculated according to the equation presented in the Materials and Methods section. Means with the same letter do not show a statistically significant difference according to the Tukey test $(\alpha=0.05)$. 
complex effects on delignification and yield suggest that complex optimisation designs intended to optimise both variables should be applied. For instance, Wan Omar and Amin (2016) carried out the optimisation of oil palm frond pre-treatment by ozonolysis using a multi-response analysis with a desirability function, wherein lignin degradation and total reducing sugars recovery were used as optimisation targets.

In contrast to what happened in the kraft and anthraquinone pulping, the samples treated with hydrogen peroxide and peroxymonophosphoricacid presented a high yield that was close to $74 \%$, which means that no significant loss of mass had occurred. It is generally expected that these methods result in a higher pulp yield because their mechanism of delignification is based on the capacity of the peroxy acids and $\mathrm{H}_{2} \mathrm{O}_{2}$ of hydroxylating the aromatic rings in the lignin molecule (Kadla and Chang, 2001). Consequently, the cellulose and hemicellulose polymers are less susceptible to be degraded during these pulping strategies. Other authors have also reported high pulp yields using different substrates such as aspen wood or rice straw (Springer, 1997; Verma et al., 2011).

For the biological methods, when the crude extract of Xylaria sp. was used, the yield detected was approximately $97 \%$, in contrast to the percentage of efficiency observed in treatments based on the direct fungal growth on the palm fibres. In the latter case, the treatments resulted in a radical reduction of the initial mass after 90 days of SSF. Notably, the yield of the treatment with Psilocybe sp. was less than $45 \%$. Other authors have evaluated the total weight loss after a fungal treatment such as Singh et al. (2013), who used Trametes versicolor to degrade oil palm trunk chips, achieving $8.45 \%$ of weight loss after
30 days of incubation. Also, Piñeros-Castro and Velásquez-Lozano (2014) reported that Pleorutus ostreatus and Pleorotus chrysosporium were able to cause $43 \%$ and $33 \%$ of weight loss in oil palm EFB after four weeks of incubation, respectively. The weight loss is influenced by the degradation rate, which in turn depends on the type of fungal rot (white, brown, or soft), and the specific strains. In that sense, high variability is expected in weight loss when using a soft rot (Xylaria sp.), white rot (Agrocybe sp.), and an uncategorised wood degrader (Psilocybe sp.).

Minimal loss of mass with respect to the initial mass is important and desirable if the intention is to utilise the cellulose from the treated waste, but this outcome must be complemented with efficient lignin removal. For this reason, the percentage of lignin, cellulose and hemicellulose was determined before and after each treatment to allow the observation of the change in the rachis composition. Additionally, the quantitative loss of each component was calculated to determine whether the delignification of each treatment was general or selective.

\section{Effect of Chemical and Biological Treatments on the Rachis Fibres Composition}

The determination of the waste composition after the application of each chemical treatment demonstrated that all of the methods lead to a reduction in the lignin and hemicellulose concentration in the rachis, increasing the cellulose concentration. These results suggest that there is a minimal effect on this component during these treatments (Figure 1). The chemical treatments are classified into two groups according to their lignin content reduction. The first group corresponds to

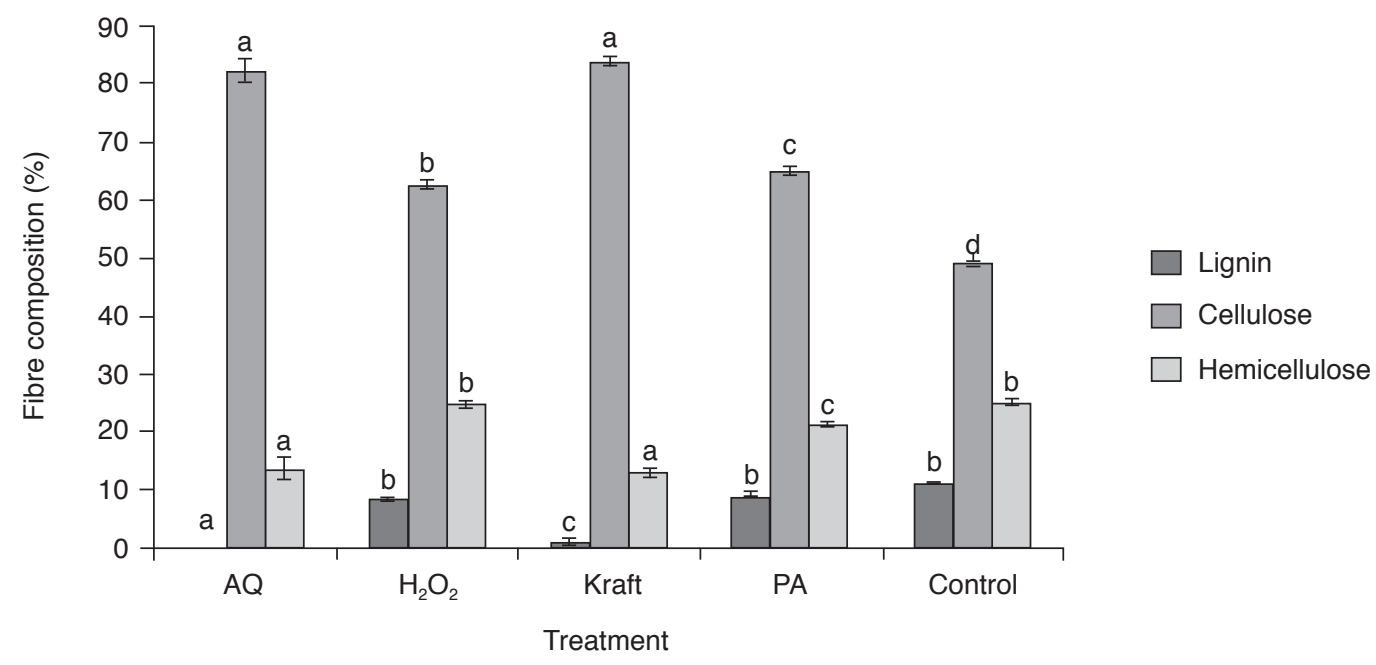

Figure 1. Composition of samples before and after the application of the chemical treatments. A significantly higher reduction was observed in lignin content with respect to the control for the kraft pulp and anthraquinone (AQ) pulping methods compared to the processes using hydrogen peroxide $\left(\mathrm{H}_{2} \mathrm{O}_{2}\right)$ and peroxy-monophosphoric acid (PA). Means with the same letter show no statistically significant difference according to the Tukey test $(\alpha=0.05)$. 
those methods using hydrogen peroxide and peroxymonophosphoric acid, which are characterised by a discrete effect that reduces the lignin content by 1.2 and 1.3 times, respectively, with respect to the control. The second group corresponds to a larger delignification effect as seen in the kraft pulping and the soda-anthraquinone pulping processes, in which the lignin concentration is reduced by 10 times, reaching final concentrations of approximately $1 \%$ lignin. With these two methods, a greater reduction in hemicellulose occurs, which might be associated with the characteristic thermal degradation suffered by sugars (Whistler and Daniel, 1985), as these methods are conducted at a temperature of $160^{\circ} \mathrm{C}$. In contrast, the enrichment of cellulose could be attributed to the structure of the polymer, which is complex and organised, with protofibres that are associated with cellulose fibres and microfibres (Lynd et al., 2002). This renders cellulose more recalcitrant than hemicellulose, a polymer with a less compact structure.

As for the biological treatments, two different approaches were evaluated. The first was the use of enzymatic crude extracts with high ligninolytic activity, as was the case for Xylaria sp. and its laccase activity (Castaño et al., 2015.). The second was the direct growth of fungi on the lignocellulosic wastes (Brijwani et al., 2010; Piñeros and Velásquez, 2014) to avoid an extra process in the pre-treatment of lignocellulose. In these cases, the determination of the waste composition after each treatment showed that Agrocybe sp. was the fungus that achieved the highest decrease in lignin concentration (1.8 times) compared to the other biological treatments, which presented similar values to those found in the untreated rachises (Figure 2). Notably, in the treatments involving the direct growth of Xylaria sp. and Agrocybe sp., an increase in the cellulose concentration was observed.

Even though information about the composition may show variations in the proportion of the compounds tested, indicating which of them is decreased or increased with respect to the control, a determination of the percentage of each component lost is needed to better understand the effect of each treatment, whether chemical or biological, on the hemicellulose, cellulose and lignin fibres. These results are shown in Table 3.

As shown in Table 3, and consistent with observations from the composition analysis, the

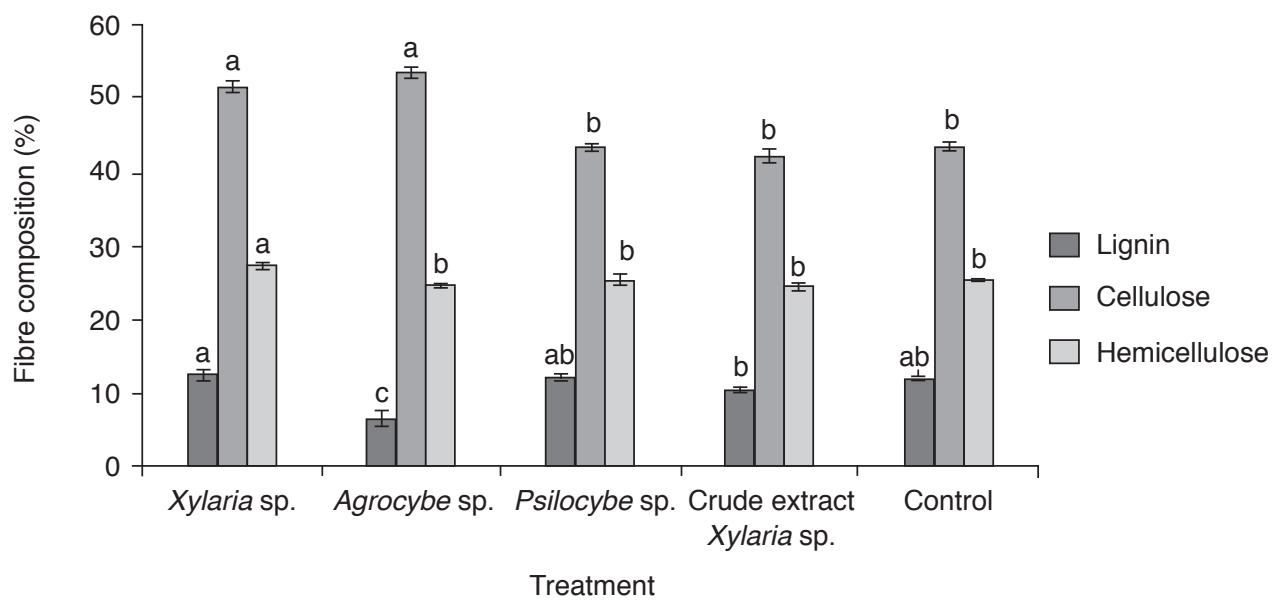

Figure 2. Composition (\%) of samples before and after application of biological treatments. Means with the same letter show no statistically significant difference according to the Tukey test $(\alpha=0.05)$. Controls for the crude extract extract treatment and the incubation treatments were not statistically different from each other. Therefore, they are presented in the figure as one control for better clarity.

TABLE 3. PERCENTAGE OF FIBRE LOSS FOR EACH APPLIED TREATMENT

\begin{tabular}{lccc}
\hline Treatment & \% Lost hemicellulose & $\%_{\text {Lost cellulose }}$ & $\%$ Lost lignin \\
\hline Chemical & & & \\
$\quad$ Kraft pulping & $75.57 \pm 0.37^{\mathrm{b}}$ & $18.84 \pm 1.21^{\mathrm{c}}$ & $94.43 \pm 0.08^{\mathrm{a}}$ \\
Soda-anthraquinone pulping & $82.96 \pm 0.70^{\mathrm{a}}$ & $47.64 \pm 0.97^{\mathrm{b}}$ & $99.86 \pm 0.19^{\mathrm{a}}$ \\
Hydrogen peroxide & $26.83 \pm 1.86^{\mathrm{f}}$ & $4.10 \pm 0.31^{\mathrm{f}}$ & $40.09 \pm 1.89^{\mathrm{c}}$ \\
$\quad$ Peroxy-monophosphoric acid & $37.45 \pm 0.52^{\mathrm{d}}$ & $1.76 \pm 0.28^{\mathrm{f}}$ & $37.83 \pm 1.57^{\mathrm{c}}$ \\
Biological & & & \\
Agrocybe sp. & $32.08 \pm 0.79^{\mathrm{e}}$ & $14.88 \pm 2.0^{\mathrm{d}}$ & \\
Psilocybe sp. & $58.13 \pm 1.12^{\mathrm{c}}$ & $58.58 \pm 0.37^{\mathrm{a}}$ & \\
$\quad$ Xylaria sp. & $16.34 \pm 1.18^{\mathrm{g}}$ & $8.80 \pm 1.61^{\mathrm{e}}$ & \\
Crude extract Xylaria sp. & $4.64 \pm 1.87^{\mathrm{h}}$ & $16.75 \pm 1.19^{\mathrm{cd}}$ & $19.08 \pm 4.78^{\mathrm{d}}$ \\
\hline
\end{tabular}

Note: Means with the same letter are not statistically significantly different according to the Tukey test $(\alpha=0.05)$. 
kraft method and the soda-anthraquinone pulping process were the chemical treatments with the highest delignification effect on the starting material, almost completely removing the lignin (>94\%). In the same way, a high loss of hemicellulose was presented in these treatments, exceeding 75\% in both cases. Notably, despite the enrichment of cellulose observed in the waste (Figure 1), an important degradation of cellulose was observed, especially through the soda-anthraquinone process, where almost $50 \%$ of this material was lost. Although carbohydrates tend to be resistant to basic hydrolysis, high temperatures can result in the thermal degradation of sugars (Whistler and Daniel, 1985), thereby explaining this observation. From this analysis, these treatments can be considered to be suitable if the objective is to maximally degrade the lignin waste for the subsequent use of cellulose. This is particularly interesting in fields such as the paper industry, wherein the strength of the product is associated with high cellulose content (Ververis et al., 2004). However, in many cases, the harnessing of cellulose may be achieved just by reducing other components such as lignin and hemicellulose. Indeed, the removal of hemicellulose can cause a decrease in the mechanical strength that prevents access to cellulose due to the role of the cross-linking features of the polymeric chains of hemicellulose, which generate stronger associations between cellulose microfibres. This mechanical strength decrease also allows the remaining cellulose fibres to swell (Zhao et al., 2009; Sun et al., 2000), which in the end contributes to a higher subsequent hydrolysis potential. Considering the above, the treatments using hydrogen peroxide and peroxymonophosphoric acid constitute two important alternatives for the selective delignification of oil palm EFB, which additionally present higher yield and omit the use of aggressive conditions of pressure and temperature.

In general, the chemical treatments are characterised by the production of adverse environmental effects during the process, especially in the kraft method (Pokhrel and Virara Ghavan, 2004). Therefore, the strategy of using biological treatments that generate less pollution is an important option to explore. In this case, the most outstanding alternatives are those involving the direct growth of the fungus over the use of the crude extract from Xylaria sp. given the higher reduction achieved in the hemicellulose, cellulose and lignin content in the direct growth strategies. The development of the organism directly on the waste supposes that the fungus must modify the lignin to access the cellulose, which is used as the carbon source (Tuomela et al., 2000), thus, explaining the effectiveness of the direct growth methods. Additionally, enzyme secretion is maintained throughout the incubation period, which contributes to improve the substrate degradation, as reported by Manjarrés et al. (2011). In contrast, when using the crude extract of the fungus, a significant loss of enzyme activity occurs beyond the second day of incubation (data not shown), restricting the enzyme effect to a short period and limiting the degradation of the vegetal material. Notably, the direct growth strategies generate a non-selective loss of lignin that can be attributed to the presence of glycosyl hydrolases (i.e., endoglucanases, mannanases, xylanases, pectinases, etc.) that degrade cellulose and other cell wall components. In this regard, for instance, the fungus Xylaria sp. has been described as a soft rot fungus, characterised by a moderate degradation of lignin and cellulose (Schwarze, 2007; Hatakka and Hammel, 2010; Liers et al., 2011), which may explain the low rate of lignin loss. In contrast, Psilocybe sp. degrades the three evaluated components in similar proportions, explaining the lack of selectivity to one of the fibres of interest. This unspecific activity has also been reported for other white rot fungi from the order Agaricales, including Pholiota conissans, Mycena sp. and Lycoperdon sp. (Barrasa et al., 2014). Based on these results, the Psilocybe sp. fungi could be used in bioremediation or biofertilisation processes in which further degradation of the cell wall components is required (Gandahi and Hanafi, 2014). On the other hand, the effect achieved by the fungus Agrocybe sp. could be considered to be selective, as it achieves a high loss of lignin $(61.44 \%)$ and a decrease of only around $15 \%$ of cellulose, coinciding with the results reported for other basidiomycete species (Nerud et al., 1991; Blanchette, 1995; Piñeros and Velásquez, 2014).

In the case of biological treatments, the effect on the rachis structure was evaluated using SEM. In agreement with the percentage loss for each component discussed above, the SEM images showed that each of the tested fungi degraded the cell wall in a different manner depending on the strain, either selectively (Agrocybe sp.), indiscriminately (Psilocybe sp.) or with only a slight modification, as observed with Xylaria sp. (Figure 3).

To sum up, the comparison of chemical and biological treatments used for the delignification of oil palm waste revealed that obtaining selective lignin degradation is possible, especially through chemical treatments and also by using the Agrocybe sp. fungus. Thus, this organism shows a great potential to be applied in pre-treatments of lignocellulosic oil palm wastes, constituting a good environmental-friendly delignification alternative. Additionally, the treatment with the fungus Psilocybe sp. could be useful not only in bioremediation, given the high degradation rates, but also in biofertilisers production, considering that mineralisation can accelerate the availability of nutrients and organic matter (Huang et al., 2008). 


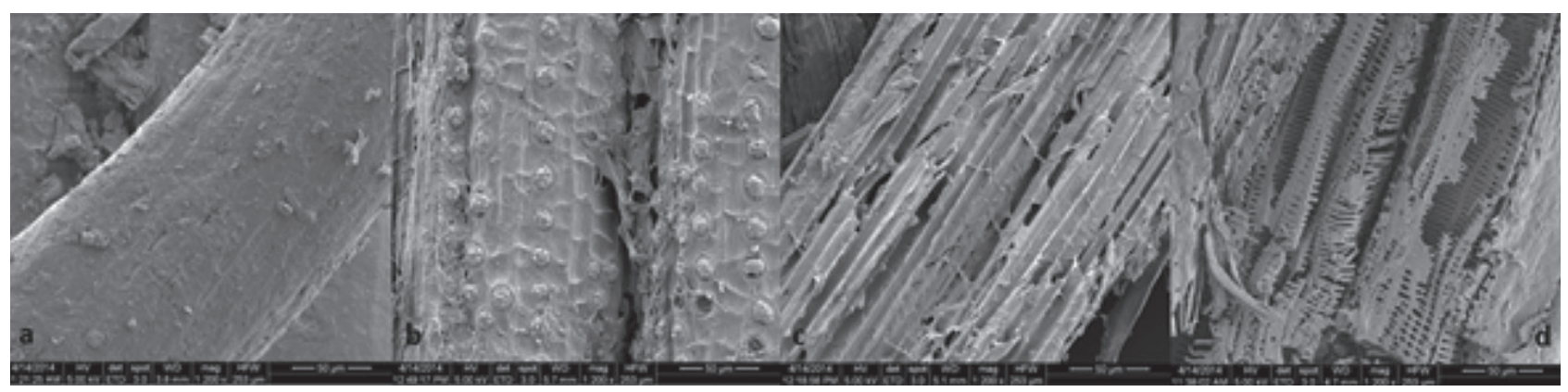

Figure 3. Images obtained by scanning electron microscopy (SEM) of palm fibres biologically treated for three months: a. Control, $b$. Xylaria sp., c. Agrocybe $s p$. and $d$. Psilocybe $s p$.

\section{CONCLUSION}

Chemical treatments that are widely used in the industry to remove lignin such as the kraft method and the soda-anthraquinone pulping process, showed the greatest reduction in lignin content from the oil palm EFB. This reduction was accompanied by an enrichment of cellulose in the waste, which potentiates the oil palm wastes for use in various processes of industrial interest.

In the analyses of the biological treatments, that with the fungi Agrocybe sp. is noteworthy. This fungus presented the greatest selectivity during the degradation process. As a result, this strain could be used in the pre-treatment processes, especially in cases in which there is a need to reduce the lignin content. The Psilocybe sp. fungal strain achieved a reduction superior to $50 \%$ of the biomass during the 90 days of evaluation, which makes this strain useful for optimising the composting process. In general, the use of the direct growth of fungi on this substrate could be highly interesting in bioremediation processes, along with the use of other degrading organisms. However, more studies on this topic are required.

\section{ACKNOWLEDGEMENT}

We acknowledge Ariel Augusto Amaya Avila, member of the Laboratory of Heat Treatments in the Faculty of Engineering of the National University of Colombia, for helping in the implementation of the pulping treatments; Colciencias for funding this project, Code 1101-521-28715-Contract number: 6322011; Unipalma SA for the contribution of samples of vegetal material, Mary Catherine Aim, and Dr Peter Goldsbrough from Plant \& Pathology Department and Dr Christopher J Gilpin for support the SEM work at Purdue University.

\section{REFERENCES}

Anupam, K; Deepika; Swaroop, V and Lal, PS (2018). Antagonistic, synergistic and interaction effects of process parameters during oxygen delignification of Melia dubia kraft pulp. J. Clean Prod., 199: 420-430.

Arantes, V; Jellison, J and Goodell, B (2012). Peculiarities of brown-rot fungi and biochemical Fenton reaction with regard to their potential as a model for bioprocessing biomass. Appl. Microbiol. Biotechnol., 94: 323-338.

Awalludin, M F; Sulaiman, O; Hashim, R and Nadhari, W N A W (2015). An overview of the oil palm industry in Malaysia and its waste utilization through thermochemical conversion, specifically via liquefaction. Renewable and Sustainable Energy Reviews, 50: 1469-1484.

Barrasa, J M; Blanco, M N; Esteve-Reventos, F; Altes, A; Checa, J; Martinez, A T and Ruiz, F J (2014). Wood and humans decay strategies by white-rot basidiomycetes correlate with two different dye decolorization and enzyme secretion patterns on agar plates. Fungal Genetics and Biology, 72: 106-114.

Blanchette, R A (1995). Degradation of lignocellulose complex in wood. Can. J. Bot., 73: S999-S1010.

Brijwani, K; Oberoi, H S and Vadlani, P V (2010). Production of a cellulolytic enzyme system in mixed-culture solid-state fermentation of soybean hulls supplemented with wheat bran. Process Biochemistry, 45: 120-128.

Buzala, K P; Kalinowska, H; Malachowska, E and Przybysz, P (2017). The utility of selected kraft hardwood and softwood pulps for fuel ethanol production. Ind. Crop. Prod., 108: 824-830.

Castañeda, T G and Romero, H M (2012). Oil palm agro-industry subproducts composting in Colombia: State-of-the-art and research perspectives [Compostaje de subproductos de la agroindustria de palma de aceite en Colombia: estado del arte y perspectivas de investigación]. Boletín Técnico No. 31: 53.

Castaño, J D; Cruz, C and Torres, E (2015). Optimization of the production, purification and 
characterization of a laccase from the native fungus Xylaria sp. Biocatal. Agr. Biotechnol. DOI:10.1016/j. bcab.2015.09.012.

Cullen, D and Kersten, P J (2004). Enzymology and molecular biology of lignin degradation. The Mycota III: Biochemistry and Molecular Biology (Brambl, R and Marzluf, G A eds.). $2^{\text {nd }}$ Edition. Springer-Verlag Berlin-Heidelberg.

De Almeida, D P and Gomide, J L (2013). Anthraquinone and surfactant effect on soda pulping. O' Papel., 74(7): 53-56.

Fedepalma (2015). Economic balance of Colombian palm sector in 2014 [Balance económico del sector palmero colombiano en 2014]. Boletín económico. Área de Economía y Gestión Comercial Estratégica. p. 8.

Gandahi, A W and Hanafi, M M (2014). Biocomposting oil palm waste for improvement of soil fertility. Composting for Sustainable Agriculture (Maheshwari, D K ed.). Springer International Publishing, Switzerland. p. 209-243.

Hatakka, A and Hammel, K (2010). Fungal biodegradation of lignocelluloses. The Mycota: A Comprehensive Treatise on Fungi as Experimental Systems for Basic and Applied Research. Industrial Applications (Hofrichter, M ed.). Berline: Springer. p. 319-340.

Huang, H L; Zeng, G M; Tang, L; Yu, H Y; Xi X M; Cheng, Z M and Huang, G H (2008). Effect of biodelignification of rice straw on humification and humus quality by Phanerochaete crysosporium and Streptomyces badius. Int. Biodeter. Biodegr., 61: 331-336.

Infante, M; Ysambert, F; Hernández, M; Martínez, B; Delgado, N; Bravo, B; Cáceres, A; Chávez, G and Bullón, J (2007). Oxidative degradation of lignin with hydrogen peroxide assisted by microwaves and its tensoactive properties [Degradación oxidativa asistida por microondas de lignina con peróxido de hidrógeno y sus propiedades tensoactivas]. Revista Tecnica de Ingeniería de la Universidad de Zulia., 30: 108-117.

Jung, H G; Samac, D A and Sarath, G (2012). Modifying crops to increase cell wall digestibility. Plant Sci., 185-186: 65-77.

Kayikcioglu, H H (2013). Effects of composts from agro industrial wastes on microbial activity of a typic xerofluvent soil under Mediterranean conditions, SE Turkey. Geomicrobiol. J., 30(9): 228-236.

Kadla, J F and Chang, H M (2001). The reactions of peroxides with lignin and lignin model compounds.
Oxidative Delignification Chemistry: Fundamentals and Catalysis (Argyropoulos, D S ed.). Oxford University Press, Washington, DC. ACS Symposium Series 785. p. 108-129.

Kothari, R; Tyagi, V V and Pathak, A (2010). Wasteto-energy: A way from renewable energy sources to sustainable development. Renewable and Sustainable Energ. Rev., 14: 3164-3170.

Kuhad, R C; Singh, A and Eriksson, K E L (1997). Microorganisms and enzymes involved in the degradation of plant fiber cell walls. Advances in Biochemical Engineering/Biotechnology (Eriksson, K E L ed.). Springer, Germany. p. 46-125.

Leh, C P; Wan Rosli, W D; Zainuddin, Z and Tanaka, $R$ (2008). Optimisation of oxygen delignification in production of totally chlorine-free cellulose pulps from oil palm empty fruit bunch fiber. Ind. Crop. Prod., 28: 260-267.

Liers, C; Arnstadt, T; Ullrich, R and Hofrichter, M (2011). Patterns of lignin degradation and oxidative enzyme secretion by different wood- and littercolonizing basidiomycetes and ascomycetes grown on beech-wood. FEMS Microbiol. Ecol., 78: 91-102.

Lynd, L R; Weimer, P J; Van Zyl, W H and Pretorius, I S (2002). Microbial cellulose utilization: Fundamentals and biotechnology. Microbiol. Mol. Biol. Rev., 66: 506-577.

Manjarres, K; Piñeros, Y and Rodríguez, E (2011). Evaluation of the enzymatic complex produced by co-culture of Aspergillus sp. and Trichoderma sp. in solid phase fermentation over palm residues [Evaluación del complejo enzimático producido mediante el cocultivo de Aspergillus sp. y Trichoderma sp. en fase sólida sobre residuos de palma]. Bioagro., 23(1): 19-26.

Martinez, A T; Speranza, M; Ruiz-Duenas, F J; Ferreira P; Camarero, S; Guillen, F; Martinez, M J; Gutierrez, A and Del Rio, J C (2005). Biodegradation of lignocellulosics: Microbial, chemical, and enzymatic aspects of the fungal attack of lignin. Int Microbiol., 8: 195-204.

Nandkumar, P (2009). Lignin from soda liquor and soda anthraquinone of Ipomoea carnea Jacq. Aust. J . Basic Appl. Sci., 3(2): 474-476.

Nerud, F; Zouchova, Z and Misurcova, Z (1991). Ligninolytic properties of different white rot fungi. Biotech. Lett., 13: 657-660.

Oldroyd, D L and Wadley, F M (1997). Optimization of anthraquinone pulping and oxygen delignification 
through statistical design. TAPPI Proc. of the Pulping Conference. p. 443-453.

Oudia, A; Meszáros, E; Simoes, R; Queiroz, J and Jackab, E (2007). Pyrolysis-GC/MS and TG/MS study of mediated laccase biodelignification of Eucalyptus globulus kraft pulp. J. Anal. Appl. Pyrol., 78: 233-242.

Pinto, P C R; Oliveira, C; Costa, C A; Gaspar, A; Faria, T; Ataide, J and Rodrigues, A E (2015). Kraft delignification of energy crops in view of pulp production and lignin valorization. Ind. Crop. Prod., 71: 153-162.

Piñeros-Castro, Y and Velásquez, M (2014). Biodegradation kinetics of oil palm empty fruit bunches by white rot fungi. Int. Biodeter. Biodegr., 91: 24-28.

Pokhrel, D and Virara Ghavan, T (2004). Treatment of pulp and paper mill wastewater - A review. Sci. Total Environ., 333: 37-58.

Prasertsan, S and Prasertsan, P (1996). Biomass residues from palm oil mills in Thailand: An overview on quantity and potential usage. Biom. Bioene., 11(5): 387-395.

Schwarze, F W (2007). Review: Wood decay under microscope. Fungal Biology Reviews, I: 38.

Shuit, S H; Tan, K T; Lee, K T and Kamaruddin, A $H$ (2009). Oil palm biomass as a sustainable energy resource: A Malaysian case study. Energ., 34: 12251235.

Singh, P; Sulaiman, O; Hashim, R; Peng, L C and Singh, R P (2013). Evaluating biopulping as an alternative application on oil palm trunk using the white-rot fungus Trametes versicolor. Int. Biodeterior. Biodegradation, 82: 96e103.

Springer, E L (1994). Delignification of Aspen wood with pernitric acid. Tappi J., 77(6): 103.
Springer, E L (1997). Delignification of wood and Kraft pulp with peroxymonophosporic acid. JPPS., 23(12): J582-J584.

Sun, R C; Fang, J M and Tomkinson, J (2000). Delignification of rye straw using hydrogen peroxide. Ind. Crop. Prod., 12: 71-83.

Tuomela, M; Vikman, M; Hatakka, A and Itävaara, M (2000). Biodegradation of lignin in a compost environment: A review. Bioresource Technol., 72: 169-189.

Van Soest, P J; Robertson, J B and Lewis, B A (1991). Methods for dietary fiber, neutral fiber and non-starch polysaccharides in relation to animal nutrition. J. Dairy Sci., 74: 3583-3597.

Verma, P; Watanabe, T; Honda, $\mathrm{Y}$ and Watanabe, $\mathrm{T}$ (2011). Microwave-assisted pretreatment of woody biomass with ammonium molybdate activated by $\mathrm{H}_{2} \mathrm{O}_{2}$. Bioresource Technol., 102: 3941-3945.

Ververis, C; Georghiou, K; Christodoulakis, N; Santas, P and Santas, R (2004). Fiber dimensions, lignin and cellulose content of various plant materials and their suitability for paper production. Ind. Crop. Prod., 19: 245-254.

Wan Omar, W N N and Amin, N A S (2016). Multi response optimization of oil palm frond pretreatment by ozonolysis. Ind. Crop. Prod., 85: 389-402.

Whistler, R L and Daniel, J R (1985). Carbohydrates. Food Chemistry (Fennema, P ed.). $2^{\text {nd }}$ Edition, Marcel Dekker, NY. p. 69-137.

Xian-Ling, J; Wen-Ting, Z; Ying-Ping, G; Bao-Yun, L; Chuan-Zhong, Y and Quing, Xin, L (2012). Patterns of lignocellulose degradation and secretome analysis of Trametes trogii MT. Int. Biodeter. Biodegr., 75: 55-62.

Zhao, X; Peng, F; Cheng, K and Liu, D (2009). Enhancement of the enzymatic digestibility of sugarcane bagasse by alkali-peracetic acid pretreatment. Enzyme Microb. Tech., 44: 17-23. 